\title{
Transdermal iontophoretic delivery of timolol maleate
}

\author{
Mayur Patni ${ }^{1}$, Prashant Puranik ${ }^{1, *}$, Aravind Sonawane ${ }^{2}$, Prabhakar Panzade ${ }^{2}$ \\ ${ }^{1}$ Government College of Pharmacy, Department of Pharmaceutics, Aurangabad (MS) India ${ }^{2}$ Shri Bhagwan College of \\ Pharmacy, Department of Pharmaceutics, Aurangabad (MS) India
}

\begin{abstract}
Transdermal iontophoresis would be a promising method for the systemic delivery of water soluble and ionic drugs of relatively high molecular size, including peptides. The objective of the present study was to investigate the effect of biological variable such as guinea pig and human cadaver skin and other variables like drug concentration, current density on the transdermal iontophoretic transport of timolol maleate. The permeation profile of drug using solution and gel formulation was studied and compared. For better bioavailability, better patient compliance, and enhanced delivery, an iontophoretic drug delivery system of a timolol maleate matrix gel was formulated using Carbopol 974P. The study was conducted using silver-silver chloride electrodes across the guinea pig and human cadaver skin. Viscosity measurements and flux calculations indicated the suitability of the Carbopol 974P gel for transdermal iontophoretic delivery of timolol maleate. Anodal iontophoresis with silver-silver chloride electrode significantly increased the timolol maleate skin permeation as compared with the passive permeation study. The amount of timolol maleate transported during iontophoresis was significantly different among the different skins. However, iontophoretic gel formulations provided required flux of drug through human cadaver skin.
\end{abstract}

Uniterms: Timolol maleate/transdermal iontophoretic transport. Transdermal iontophoresis/drug release. Drugs/release. Timolol maleate/skin permeation. Carbopol gel/ transdermal iontophoretic delivery.

A iontoforese transdérmica seria um método promissor para a liberação sistêmica de fármacos solúveis em água e iônicos de relativamente elevado tamanho molecular, incluindo peptídeos. O objetivo do presente estudo foi investigar o efeito da variável biológica, tais como cobaia e pele de cadáver humano, e outras variáveis como concentração do fármaco, densidade de corrente sobre o transporte transdérmico iontoforético de maleato de timolol. Comparou-se o perfil de permeação do fármaco usando a formulação de solução e de gel. Para melhor biodisponibilidade, melhor adesão do paciente e liberação aprimorada, formulou-se sistema de liberação iontoforética gel de maleato de timolol usando Carbopol 974P. O estudo foi conduzido usando eletrodos de prata-cloreto de prata na cobaia e na pele de cadáver humano. Medidas de viscosidade e de fluxo indicaram a adequação do gel Carbopol 974 P para liberação iontoforética transdérmica do maleato de timolol. A iontoforese anódica com eletrodo de prata-cloreto de prata aumentou significativamente a permeação dérmica do maleato de timolol, comparativamente à permeação passiva. A quantidade de maleato de timolol transportado durante a iontoforese foi significativamente diferente entre as diferentes peles . No entanto, as formulações iontoforéticas de gel forneceram o fluxo necessário do fármaco através da pele de cadáver humano.

Unitermos: Maleato de timolol/transporte transdérmico iontoforético. Iontoforese transdérmica/liberação de fármacos. Fármacos/liberação. Maleato de timolol/permeação dérmica. Carbopol gel/liberação iontoforética transdérmica.

*Correspondence: Puranik Prashant K. Government College of Pharmacy, Vedant Road, 431005-Osmanpura,Aurangabad.E-mail:pkpuranik@yahoo.com; prabhakarpanzade@gmail.com 


\section{INTRODUCTION}

Iontophoresis is defined as the facilitated movement of ions of soluble salts across a membrane under an externally applied potential difference. Iontophoresis is a non-invasive drug delivery system with no trauma, risk of infection or damage to the wound and is therefore an important alternative to injection therapy (Singh, Howard, 1996; Banga, Bose, Ghosh, 1999). Iontophoresis allows controlled programmed delivery of variety of compounds. Charged drugs as well as other ions are carried across the skin as a component of induced ion flow. Iontophoresis effectively delivers a large variety of compounds across the skin (Heit, Riviere, 1997; Fitzpatrick, Corish, 2006; Kanikkannan, Singh, Ramarao, 2000). Several investigators identified that, many formulation factors like drug concentration, $\mathrm{pH}$, ion composition and current density may influence the iontophoretic transport (Green, 1996; Saraf, Dixit, 1996).

Transdermal permeation of drugs across the skin of animals like rat, rabbit and mouse is significantly higher than human skin. Most investigators prefer excised human skin for in vitro transdermal studies as it is more relevant; but its availability on regular basis limits its applications. A variety of excised animal skin like rat, rabbit and guinea pig is suitable as alternative to human skin owing to their availability (Kanikkannan, Singh, Singh, 2001; Pathan, Mallikarjun, 2008).

Timolol maleate is non-selective beta-adrenergic blocking agent without membrane stabilizing or intrinsic sympathomimetic activities. It is used in the management of hypertension, angina pectoris, myocardial infarction and glaucoma. Timolol maleate, being antihypertensive, is used to control hypertension in the elderly with doses of 10 to $40 \mathrm{mg}$ administered 2 times a day. It undergoes extensive presystemic metabolism and its elimination half life is $4 \mathrm{~h}$, ionized at physiological $\mathrm{pH}$, oral bioavailability is only $60-70 \%$ and therefore, it is an excellent candidate for transdermal iontophoresis. Timolol maleate has biological half life of 2.5 to 5 hours. For oral formulation with short biological half life and high body clearance rate, frequent dosing is required to elicit and maintain pharmacological effect. To surpass the presystemic metabolism and increase the bioavailability of timolol maleate, iontophoretic transdermal drug delivery, can be a suitable approach (Sweetman, 2007; Flory, 2005; Dimitrios, Joke, 2004). Some investigators studied the iontophoresis of timolol maleate and reported increased transport and control delivery of the drug.

The present study was aimed to assess the feasibility of electrically assisted delivery of timolol solution and gel formulation through guinea pig skin and to compare it with excised human skin. Furthermore, the transdermal timolol delivery from a Carbopol 974P matrix gel was investigated. The effect of drug concentration and current density on the timolol maleate permeation was also investigated.

\section{MATERIAL AND METHODS}

Timolol maleate (Purity 99.6\%) was obtained as a gift sample from FDC Ltd., Aurangabad, India. Carbopol 974P was purchased from Noveon, India. Potassium dihydrogen phosphate and sodium hydroxide were purchased from Merck, India. Silver chloride was purchased from Research fine lab, Mumbai. All other chemicals and reagents were of analytical grade. Silver wire (1 mm diameter, $99.9 \%$ pure) was purchased from local supplier. All solutions were prepared from Millipore water (resistance $18 \mathrm{M} \Omega$ ).

The amount of timolol maleate in the samples was quantified using UV spectrophotometer (SHIMADZU, 1700-PC, Japan).

\section{Preparation of skin samples}

Freshly excised full thickness (approximately 300$400 \mu \mathrm{m}$ ), abdominal skin of guinea pig and human cadaver was used. In all experiments, hair was removed using hair remover clipper $24 \mathrm{~h}$ before experiment taking care not to damage the stratum corneum. The human cadaver skin was prepared within $24 \mathrm{~h}$ of its removal from the body. The skin was stored at very low temperature $\left(-20^{\circ} \mathrm{C}\right)$ in sterile cotton gauze soaked in normal saline, wrapped by aluminum foil and then thawed just before use. Animal experiments were conducted in full compliance with institutional animal ethics committee (IAEC, CPCSEA, Government College of Pharmacy, Aurangabad, India).

\section{In vitro iontophoretic transport studies}

The excised skin (guinea pig, human cadaver) was mounted between donor and receptor chamber of the modified Keshary Chien diffusion cell (surface area 3.88 $\mathrm{cm}^{2}$ ) with epidermal side facing the donor fluid. The donor chamber was filled with drug solution and phosphate buffer $\mathrm{pH} 7.4$ was placed in the receptor chamber. The diffusion medium in the receptor chamber was stirred using star-headed magnetic bead bar (size $10 \times 10 \mathrm{~mm}$ ) (Himedia) rotating at constant speed of $600 \mathrm{rpm}$ by motorless magnetic mega stirrer (Whirlmatic-Mega, Spectralab) and the temperature in the bulk of the solution was maintained at a constant level of $37 \pm 1^{\circ} \mathrm{C}$ using constant 
temperature water circulating bath (Deep Engineering), which circulates thermostated water through the water jacket surrounding the receptor compartment. In all experiments, the drug solution was left in the donor chamber till the end of experiment $(7 \mathrm{~h})$. Unless stated otherwise current density was $0.5 \mathrm{~mA} / \mathrm{cm}^{2}$. Silver wire was used as anode and silver/silver chloride as the cathode. Timolol maleate is positively charged $(+1)$ at $\mathrm{pH}=7.4$ and anodal iontophoresis was used. Passive diffusion experiments were carried out without application of current to compare with iontophoretic study. Samples $(1 \mathrm{~mL})$ were withdrawn from the receptor chamber at predetermined time intervals and an equal volume of fresh diffusion medium was added to the receptor medium. The withdrawn samples were centrifuged (Spinwin, Tarsons) for $10 \mathrm{~min}$. at $1000 \mathrm{rpm}$ and analyzed by UV spectrophotometer (SHIMADZU $1700-\mathrm{PC}$ ) at $294.50 \mathrm{~nm}$. All experiments were carried out in triplicate.

\section{Effect of drug concentration on passive and iontophoretic permeation through guinea pig skin}

The experimental set up for the in vitro permeation study was similar to as described previously in the above section. In this study, $3 \mathrm{ml}$ of timolol solution in phosphate buffer $\mathrm{pH} 7.4$ at different concentrations $(10,20,30$ and 40 $\mathrm{mg} / \mathrm{ml}$ ) were added to donor compartment. Iontophoretic application was comprised of direct continuous current of $0.5 \mathrm{~mA} / \mathrm{cm}^{2}$ using silver-silver chloride electrode. Amount of timolol maleate permeated was estimated by using UV spectrophotometer (SHIMADZU 1700-PC) at $294.50 \mathrm{~nm}$. Concentration of drug to be taken for further study was optimized based on the results.

\section{Effect of current density on permeation through guinea pig skin}

The influence of current density on transport of Timolol maleate across guinea pig skin was investigated at the same anodal conditions, as described for transport studies. The current density was varied from 0.2 to 0.4 and to $0.5 \mathrm{~mA} / \mathrm{cm}^{2}$.

\section{In vitro permeation study through human cadaver skin}

The experimental set up for the in vitro permeation study was similar to as described previously in the above section. Donor compartment comprised of $3 \mathrm{~mL}$ of $30 \mathrm{mg} / \mathrm{mL}$ timolol maleate solution and current density of $0.5 \mathrm{~mA} / \mathrm{cm}^{2}$ was applied for iontophoretic application. Amount of timolol maleate permeated was estimated by using UV spectrophotometer.

\section{Preparation of Carbopol 974P matrix gel}

Previously weighed quantity of Carbopol 974P at concentration ( 1 and $1.5 \% \mathrm{w} / \mathrm{w}$ ) was slowly dispersed into sufficient quantity of water, with continuous mixing until Carbopol 974P swelled completely. During gel preparation, the solution was agitated slowly to avoid introduction of air bubbles. A $30 \mathrm{mg} / \mathrm{g}$ of timolol maleate was incorporated by mixing with sufficient quantity of water. The effect of neutralizing agent to the above solution was studied by adding triethanolamine in a concentration of 1.75 and $2 \% \mathrm{w} / \mathrm{w}$ respectively and agitated for $30 \mathrm{~min}$ to obtain a gel (Table I).

The resultant gels were subjected for clarity, consistency, drug content (by UV spectrophotometer) and viscosity (Brookfield R/S plus Rheometer and spindle no.C25-2) determination. All gels were tested for in vitro permeation through guinea pig skin.

\section{In vitro permeation of timolol maleate from Carbopol 974P matrix gel through guinea pig skin and human cadaver skin via passive and iontophoretic process}

The effect of matrix gel on timolol maleate permeation was studied by subjecting all the gel formulations (F1, F2, F3 and F4) for passive and iontophoretic permeation through guinea pig skin and human cadaver skin. Gel formulation ( $3 \mathrm{~g}$ ) was applied to epidermal side of membrane. The optimized gel formulation was subjected to passive and iontophoretic permeation study through hu-

TABLE I - Composition of Carbopol gels

\begin{tabular}{lcccc}
\hline Formulation code & Carbopol $974 \mathrm{P}(\% \mathrm{w} / \mathrm{w})$ & Timolol maleate $(\mathrm{mg} / \mathrm{g})$ & Triethanolamine $(\% \mathrm{w} / \mathrm{w})$ & Water $(\mathrm{g})$ \\
\hline F1 & 1 & 30 & 1.75 & 10 \\
F2 & 1 & 30 & 2 & 10 \\
F3 & 1.5 & 30 & 1.75 & 10 \\
F4 & 1.5 & 30 & 2 & 10 \\
\hline
\end{tabular}


man cadaver skin. Amount of timolol maleate permeated was estimated by using UV spectrophotometer.

\section{Data analysis}

The real steady-state situation was not observed clearly during permeation studies. Therefore cumulative amount of timolol maleate permeated per unit surface area of skin was plotted against time and the slope of the linear portion of the plot was estimated as steady-state flux (Julraht, Keith, James, 1995) The enhancement ratio (Er) for the flux was calculated by using Equation $\mathrm{Er}=$ Iontophoretic Flux/Passive Flux and Permeability coefficient (Kp) was calculated using equation $\mathrm{Kp}=\mathrm{Flux} /$ Initial amount of drug in donor compartement (Oh H, Oh Y, Kim, 2001; Kotwal, Bhise, Thube, 2007). The permeation parameters obtained were compared by one-way analysis of variance (ANOVA). Tukey-Kramer test and Dunnett test were performed for multiple comparisons amongst the different formulations, respectively. The probability level, $\mathrm{p}<0.001$, was considered statistically significant and probability level $\mathrm{P}>0.05$, was considered statistically insignificant.

\section{RESULTS AND DISCUSSION}

\section{Effect of drug concentration}

Effect of drug concentration $(10,20,30 \mathrm{mg} / \mathrm{mL})$ on the passive and iontophoretic permeation from vehicle formulations through guinea pig skin was studied and permeation profiles are as shown in Figure 1.

Statistically significant differences were observed in flux ( $\mathrm{P}<0.001)$ with $20 \mathrm{mg} / \mathrm{mL}, 30 \mathrm{mg} / \mathrm{mL}$ passive and iontophoretic application. Highest flux of $20.832 \pm 2.08$ and $456.755 \pm 38.67 \mu \mathrm{g} / \mathrm{cm}^{2} / \mathrm{h}$ was obtained from $30 \mathrm{mg} /$ $\mathrm{mL}$ solution when evaluated for passive and iontophoretic application respectively as shown in Table II. As there was linear increase in the flux with passive and iontophoretic process, $30 \mathrm{mg} / \mathrm{mL}$ drug concentration was selected as

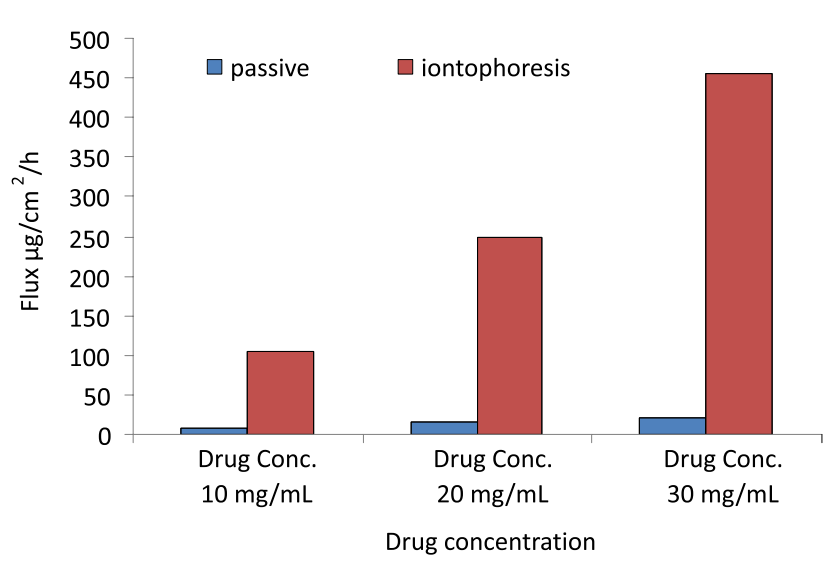

FIGURE 1 - Comparison of effect of drug concentration.

optimized drug concentration for the further studies. This may be attributed to the fact that as concentration gradient increase across the skin, flux also increases in accordance with accepted theory. (Kalia et al., 2004).

\section{Effect of current density}

The variation in the current density has marked influence on permeation of drugs through membrane. In general $0.5 \mathrm{~mA} / \mathrm{cm}^{2}$ is often stated to be the maximum iontophoretic current which should be used on human being (Banga, 1998; Lawler, Devis, Giiffith, 1960; Kalia et al., 2004). The extent of charged molecules, which may penetrate through the skin, are proportional to the density of current and the duration of treatment for a transdermal iontophoretic delivery.

Effect of current density $\left(0.2,0.4,0.5 \mathrm{~mA} / \mathrm{cm}^{2}\right)$ on the permeation from vehicle formulations through guinea pig skin was studied and permeation profiles are presented in Table III.

Statistically significant differences $(\mathrm{P}<0.001)$ were observed between the flux of drug solution when evaluated for different current densities $\left(0.2,0.4,0.5 \mathrm{~mA} / \mathrm{cm}^{2}\right)$ and compared with passive application respectively, as shown in Figure 2. The maximum flux of $456.755 \pm 38.67 \mu \mathrm{g} / \mathrm{cm}^{2} / \mathrm{h}$

TABLE II - Effect of drug concentration

\begin{tabular}{lcccccc}
\hline & \multicolumn{6}{c}{ Drug Concentration $(\mathrm{mg} / \mathrm{mL})$} \\
\cline { 2 - 6 } & 10 & 10 & 20 & 20 & 30 & 30 \\
\hline $\begin{array}{l}\text { Permeation } \\
\text { parameter }\end{array}$ & Passive & Iontophoresis & Passive & Iontophoresis & Passive & Iontophoresis \\
Jss $\left(\mu \mathrm{g} / \mathrm{cm}^{2} / \mathrm{h}\right)$ & $7.851 \pm 1.10$ & $103.785 \pm 3.92^{\mathrm{a}}$ & $16.813 \pm 0.58^{\mathrm{b}}$ & $247.697 \pm 4.51^{\mathrm{a}}$ & $20.832 \pm 2.08^{\mathrm{b}}$ & $456.755 \pm 38.67^{\mathrm{a}}$ \\
$\mathrm{Kp}$ & $0.000238 \pm 0.0001$ & $0.0033 \pm 0.0014^{\mathrm{a}}$ & $0.00027 \pm 0.00010^{\mathrm{b}}$ & $0.0040 \pm 0.0009^{\mathrm{a}}$ & $0.000278 \pm 0.000067^{\mathrm{a}}$ & $0.0047 \pm 0.0012^{\mathrm{b}}$ \\
\hline
\end{tabular}

$\mathrm{Jss}=$ Steady state flux, $\mathrm{Kp}=$ Permeability coefficient; $\mathrm{a}=$ statistically significant difference from passive study $(\mathrm{P}<0.001), \mathrm{b}=$ statistically not significant difference from passive study $(\mathrm{P}>0.05)$ 
TABLE III - Effect of current density

\begin{tabular}{|c|c|c|c|c|}
\hline \multirow{3}{*}{ Permeation parameter } & \multicolumn{4}{|c|}{ Current Density $\left(\mathrm{mA} / \mathrm{cm}^{2}\right)$} \\
\hline & & 0.2 & 0.4 & 0.5 \\
\hline & Passive & Iontophoresis & Iontophoresis & Iontophoresis \\
\hline$\overline{\mathrm{Q}_{7}\left(\mu \mathrm{g} / \mathrm{cm}^{2}\right)}$ & $295.97 \pm 24.41$ & $1467.71 \pm 32.11^{\mathrm{a}}$ & $2424.51 \pm 44.50^{\mathrm{a}}$ & $5143.21 \pm 68.01^{\mathrm{a}}$ \\
\hline $\mathrm{Jss}\left(\mu \mathrm{g} / \mathrm{cm}^{2} / \mathrm{hr}\right)$ & $20.832 \pm 2.08$ & $203.391 \pm 14.35^{\mathrm{a}}$ & $328.759 \pm 16.35^{\mathrm{a}}$ & $456.755 \pm 38.67^{\mathrm{a}}$ \\
\hline Kp & $0.000278 \pm 0.000067$ & $0.00237 \pm 0.0012^{\mathrm{b}}$ & $0.00378 \pm 0.0026^{\mathrm{a}}$ & $0.0047 \pm 0.0012^{\mathrm{b}}$ \\
\hline ER & 1 & 9.763 & 15.781 & 21.925 \\
\hline
\end{tabular}

Q7 = Cumulative amount permeated in $7 \mathrm{~h}, \mathrm{Jss}=$ Steady state flux, $\mathrm{Kp}=$ Permeability coefficient, ER= Enhancement ratio. $\mathrm{a}=$ statistically significant difference from passive study $(\mathrm{P}<0.001), \mathrm{b}=$ statistically not significant difference from passive study $(\mathrm{P}>0.05)$

at current density of $0.5 \mathrm{~mA} / \mathrm{cm}^{2}$ was obtained and found to be significantly higher than flux of passive and other current densities $\left(0.2,0.4 \mathrm{~mA} / \mathrm{cm}^{2}\right)$. Hence $0.5 \mathrm{~mA} / \mathrm{cm}^{2}$ current density has been selected for further studies (Panzade et al., 2012).

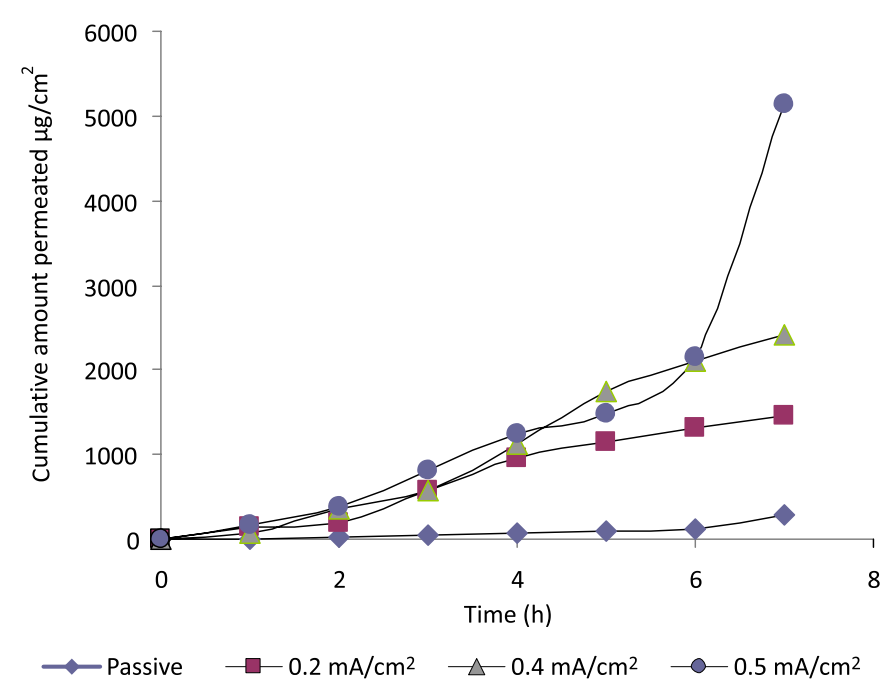

FIGURE 2 - Effect of current density.

\section{Ex vivo permeation study through human cadaver skin}

It has been reported that various factors which affects the permeation of drug includes, drug concentration, current density, temperature, and type of membrane. It has also been reported that human skin is primary in vitro model for skin permeability studies and gives more reliable data than other types of membranes. Therefore a comparative permeation study was carried out for timolol maleate through guinea pig skin and human cadaver skin via passive and iontophoresis process.

Statistically significant difference $(\mathrm{P}<0.001)$ in flux was observed between the guinea pig skin and human cadaver skin via passive and iontophoretic application.
The flux of $30 \mathrm{mg} / \mathrm{mL}$ solution formulation through excised guinea pig skin and human cadaver skin was found to be $456.755 \pm 38.67 \mu \mathrm{g} / \mathrm{cm}^{2} / \mathrm{h}$ and $59.974 \pm 0.755 \mu \mathrm{g} / \mathrm{cm}^{2} / \mathrm{h}$ respectively via iontophoretic application with enhancement ratio of 21.925 and 9.735 respectively at $0.5 \mathrm{~mA} / \mathrm{cm}^{2}$ as shown in Figure 3.

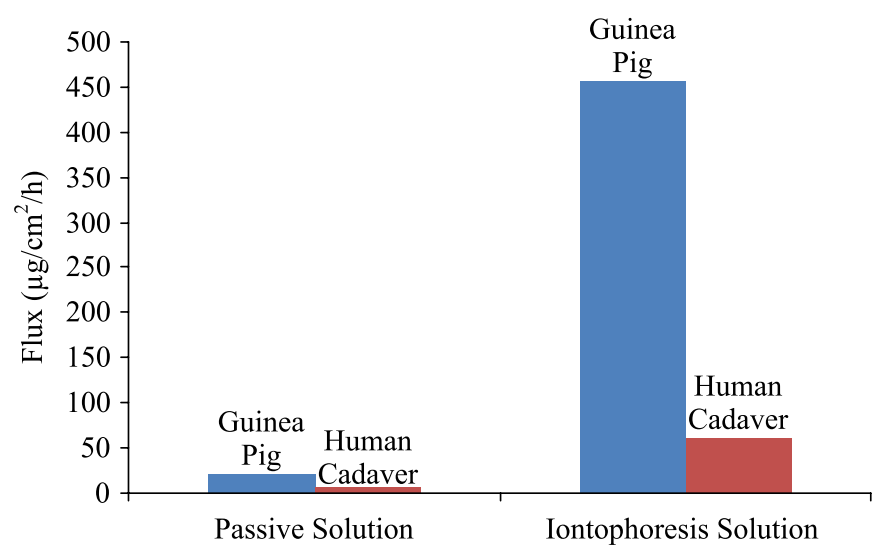

FIGURE 3 - Comparison of drug solution through guinea pig and human skin.

\section{In vitro permeation of timolol maleate from Carbopol 974P matrix gel}

Gels are clinically acceptable delivery systems for iontophoresis in terms of stability and ease of handling and refilling of iontophoretic patches (Valenta, Auner, 2004; Nair et al., 2012). The aim of this study was to evaluate in vitro permeation of timolol maleate from prepared gel formulations viz. F1, F2, F3 and F4 through guinea pig skin via passive and iontophoretic process. The flux obtained from the different gel formulations via passive and iontophoretic process are summarized in Table IV.

The study demonstrates that, there was linear decrease in flux via passive and iontophoretic application 
TABLE IV - Evaluation and permeation study of gels via passive and iontophoretic process

\begin{tabular}{lccccccc}
\hline $\begin{array}{l}\text { Formulation } \\
\text { Code }\end{array}$ & Dilution $\mathrm{pH}$ & $\begin{array}{c}\text { Drug Content } \\
(\mathrm{mg} / \mathrm{g})\end{array}$ & $\begin{array}{c}\text { Viscosity } \\
(\mathrm{Pa} / \mathrm{Sec})\end{array}$ & Clarity & Consistency & $\begin{array}{c}\text { Passive } \\
\left(\mu \mathrm{g} / \mathrm{cm}^{2} / \mathrm{h}\right)\end{array}$ & $\begin{array}{c}\text { Iontophoretic } \\
\left(\mu \mathrm{g} / \mathrm{cm}^{2} / \mathrm{h}\right)\end{array}$ \\
\hline F1 & $7.1 \pm 0.41$ & 28.81 & $0.5485 \pm 0.016$ & + & + & $17.086 \pm 0.98$ & $108.81 \pm 16$ \\
F2 & $7.6 \pm 0.25$ & 29.49 & $0.6824 \pm 0.0108$ & +++ & +++ & $9.60 \pm 0.98$ & $96.00 \pm 0.76$ \\
F3 & $6.51 \pm 0.55$ & 29.36 & $23.74 \pm 0.305$ & ++ & ++ & $6.99 \pm 0.83$ & $84.22 \pm 1.53$ \\
F4 & $6.83 \pm 0.16$ & 28.26 & $39.74 \pm 0.48$ & + & + & $3.72 \pm 0.54$ & $65.97 \pm 1.13$ \\
\hline
\end{tabular}

through guinea pig skin with increase in the viscosity of the gel formulations as seen in Figure 4.

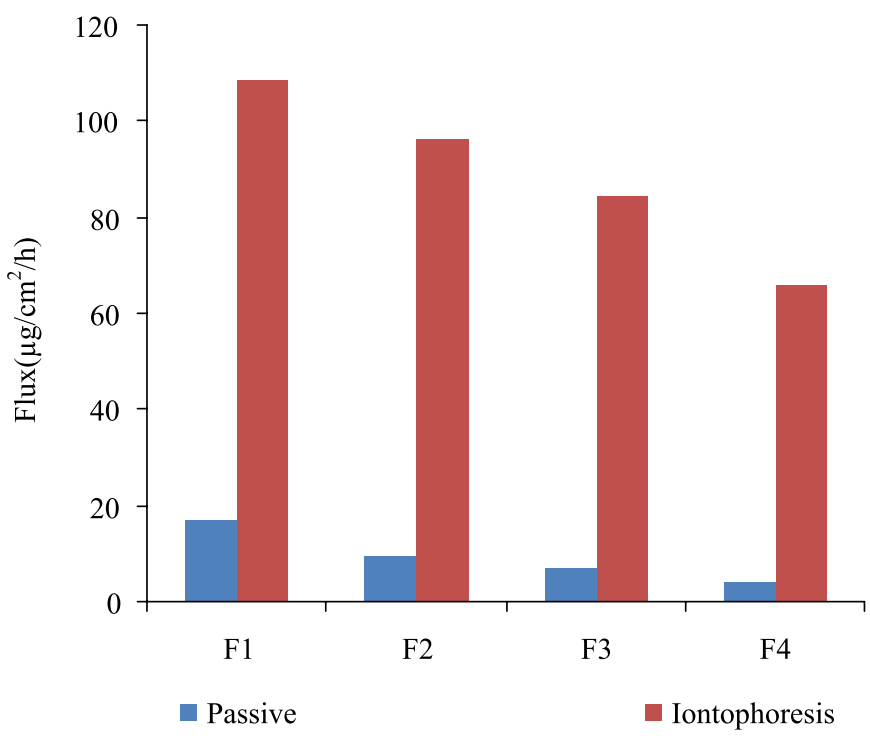

FIGURE 4 - Comparison of gel formulations through guinea pig skin.

The $\mathrm{pH}$ and relative viscosities of Carbopol gels were found to increase with the increase in the concentrations of conventional neutralizing agent triethanolamine (Zhang, Schung, 1996). Increasing the amount of the polymer in the formulations decreased the apparent flux from the formulations but increased the time it took for the drug to leave the formulation and to diffuse into the receptor medium (Edsman, Carlfors, Harju, 1996; Bounoure et al., 2008). Although maximum flux was obtained for F1 formulation, F2 formulation was selected for further studies because of viscosity and other evaluation parameters of F2 formulation. The optimized formulation F2 showed flux value of $9.60 \pm 0.98$ and $96.00 \pm 0.76 \mu \mathrm{g} / \mathrm{cm}^{2} / \mathrm{h}$ for passive and iontophoretic application respectively at viscosity of $0.6824 \pm 0.0108 \mathrm{~Pa} / \mathrm{s}$. Thus, the concentration of Carbopol $974 \mathrm{P}$ was optimized to produce a gel with enough viscosity to hold the formulation in the electrode cavity when the electrode is applied to the skin.
The optimized formulation was subjected further to permeation study by using human cadaver skin. Permeation of drug greatly varies with skin because of wide differences in physical characteristic of skin such as appendages per unit area, thickness and structural changes between human and guinea pig skin. Statistically significant difference $(\mathrm{P}<0.001)$ in flux was observed between the guinea pig skin and human cadaver skin via passive and iontophoretic application as shown in Figure 5. The flux for formulation F2 through excised guinea pig skin and human cadaver skin was found to be; $96.00 \pm 0.76 \mu \mathrm{g} / \mathrm{cm}^{2} / \mathrm{h}$ and $23.27 \pm 4.239 \mu \mathrm{g} / \mathrm{cm}^{2} / \mathrm{h}$ respectively via iontophoretic application with enhancement ratio of 10 and 9 respectively.

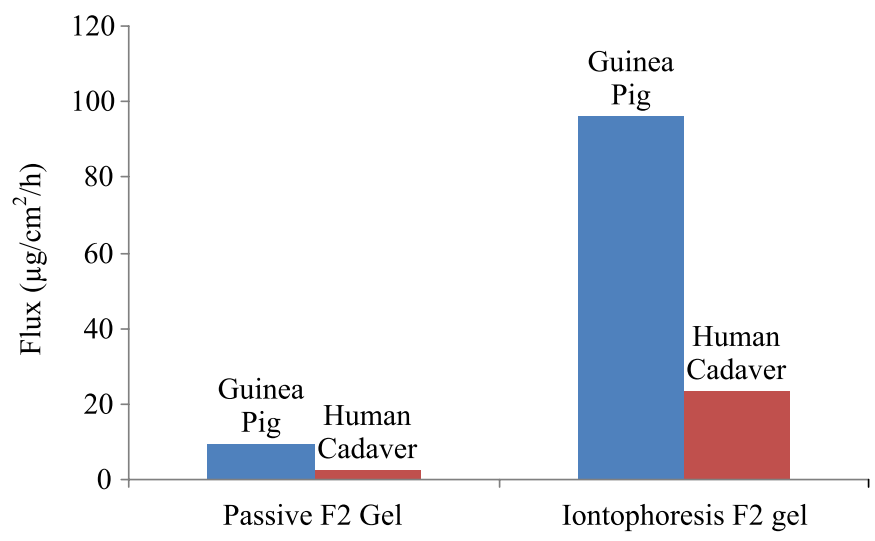

FIGURE 5- Comparison of optimized (F2) carbopol matrix gel across different skin.

Skin appendages which include sweat glands and hair follicles are considered to be major pathways of drug transport during iontophoresis. During iontophoresis, the greatest concentration of ionized species is expected to move into some regions of the skin where there is damage, or along the sweat glands and hair follicles, as the diffusional resistance of the skin to permeation is lowest in these regions. Thus, pore pathway is generally assumed for iontophoretic delivery. The significant increase in flux was observed through guinea pig skin, as compared to human cadaver skin. This may be due to the difference in 
TABLE V - Comparative permeation of drug solution and gel through different skin

\begin{tabular}{lcccccccc}
\hline \multirow{2}{*}{$\begin{array}{l}\text { Permeation } \\
\text { parameters }\end{array}$} & \multicolumn{6}{c}{ Permeation of drug solution and F2 gel through skin of different species } \\
\cline { 2 - 8 } & \multicolumn{2}{c}{ Guinea pig skin } & \multicolumn{2}{c}{ Human cadaver skin } & \multicolumn{2}{c}{ Guinea pig skin } & \multicolumn{2}{c}{ Human cadaver skin } \\
\cline { 2 - 8 } & P-Sol & P-Gel & P-Sol & P-Gel & I-Sol & I-Gel & I-Sol & I-Gel \\
\hline $\mathrm{Jss} \mu \mathrm{g} / \mathrm{cm}^{2} / \mathrm{h}$ & $20.832 \pm 2.08$ & $9.60 \pm 0.98^{\mathrm{a}}$ & $6.160 \pm 0.875^{\mathrm{a}}$ & $2.36 \pm$ & $456.755 \pm$ & $96.00 \pm 0.76^{\mathrm{a}}$ & $59.974 \pm$ & $23.27 \pm$ \\
& & & & $0.875^{\mathrm{a}}$ & $38.67^{\mathrm{a}}$ & & $0.755^{\mathrm{a}}$ & $4.239^{\mathrm{a}}$ \\
$\mathrm{Kp}$ & $0.000278 \pm$ & $0.000098 \pm$ & $0.000068 \pm$ & $0.000026 \pm$ & $0.0047 \pm$ & $0.00107 \pm$ & $0.000663 \pm$ & $0.0002 \pm$ \\
& 0.000067 & $0.00001^{\mathrm{a}}$ & $0.000021^{\mathrm{b}}$ & $0.0000081^{\mathrm{a}}$ & $0.0012^{\mathrm{a}}$ & $0.00015^{\mathrm{a}}$ & $0.00038^{\mathrm{a}}$ & $0.00006^{\mathrm{a}}$ \\
$\mathrm{ER}$ & 1 & 1 & 1 & 1 & 21.925 & 10 & 9.735 & 9 \\
\hline
\end{tabular}

$\mathrm{Jss}=$ Steady state flux, $\mathrm{Kp}=$ Permeability coefficient, $\mathrm{ER}=$ Enhancement ratio, $\mathrm{P}$-sol = passive solution, P-gel = passive gel, I-gel= iontophoresis gel, $\mathrm{I}$-sol= iontophoresis solution. $\mathrm{a}=$ statistically significant difference from passive study $(\mathrm{P}<0.001), \mathrm{b}=$ statistically not significant difference from passive study $(\mathrm{P}>0.05)$

hair follicles of human cadaver skin $\left(6 /\right.$ inch $\left.^{2}\right)$ and Guinea pig skin $\left(5000 /\right.$ inch $\left.^{2}\right)$. Variation in the thickness of skin may also be responsible for affecting the permeation of drug, the order of thickness of skin is as follows: Human cadaver skin $>$ Guinea pig skin.

\section{Comparison of solution and gel formulation}

The permeation profile of timolol maleate through guinea pig and human cadaver skin via passive and iontophoretic application from solution and optimized F2 Carbopol 974P matrix gel formulation was studied and is presented in Table V.

Statistically significant differences in flux $(\mathrm{P}<0.001)$ have been observed between the solution and gel formulations when evaluated through guinea pig skin and human cadaver skin via iontophoretic application. The obtained flux through guinea pig skin for iontophoretic solution formulation was higher and found to be $456.755 \pm 38.67 \mu \mathrm{g} / \mathrm{cm}^{2} / \mathrm{h}$ compared to iontophoretic gel formulation $96.00 \pm 0.76 \mu \mathrm{g} / \mathrm{cm}^{2} / \mathrm{h}$.

The obtained flux through human cadaver skin for iontophoretic solution formulation was higher and found to be $59.974 \pm 0.755 \mu \mathrm{g} / \mathrm{cm}^{2} /$ hcompared to iontophoretic gel formulation $23.27 \pm 4.239 \mu \mathrm{g} / \mathrm{cm}^{2} / \mathrm{hr}$, as shown in Figure 6.

Statistically significant differences in flux $(\mathrm{P}<0.001)$ have been observed between the solution and gel formulations when evaluated through guinea pig and human cadaver skin via passive application. The obtained flux through guinea pig skin for passive solution formulation was higher and found to be $20.832 \pm 2.08 \mu \mathrm{g} / \mathrm{cm}^{2} / \mathrm{h}$ compared to passive gel formulation $9.60 \pm 0.98 \mu \mathrm{g} / \mathrm{cm}^{2} / \mathrm{h}$. The obtained flux through human cadaver skin for passive solution formulation was higher and found to be $6.160 \pm 0.631 \mu \mathrm{g} / \mathrm{cm}^{2} / \mathrm{h}$ compared to passive gel formulation $2.36 \pm 0.875 \mu \mathrm{g} / \mathrm{cm}^{2} / \mathrm{h}$.

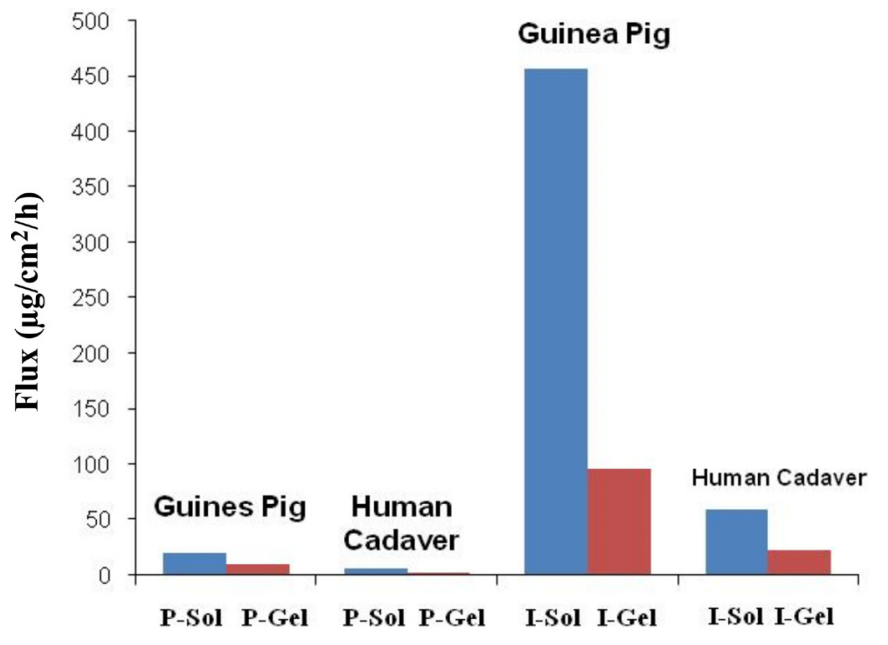

FIGURE 6 - Permeation of drug solution and optimized F2 gel through different skin.

\section{CONCLUSION}

The results of present experiment showed that timolol maleate transdermal flux increases essentially linearly as a function of its concentration and applied current density through guinea pig and human cadaver skin. Hence, timolol maleate may be excellent candidate for iontophoresis. The gel formulations showed significantly higher flux through guinea pig skin than human cadaver skin. However, iontophoretic application provided required flux when optimized gel formulation was studied over human cadaver skin. The present study demonstrated the feasibility of timolol maleate transdermal transport through Carbopol 974P gel by iontophoresis. Further more extensive in vivo studies are required to support in vitro results and to develop in vitro-in vivo correlations. 


\section{ACKNOWLEDGEMENT}

Authors are thankful to FDC Pvt Ltd, Aurangabad, for providing timolol maleate as gift sample. Authors are also thankful to Mr. Pradeep Deshmukh, (Shri Bhagwan College of Pharmacy, Aurangabad), for his help in English language review.

\section{REFERENCES}

BANGA, A.K. Electrically assisted transdermal and topical drug delivery. USA: Taylor and Francis group, 1998. p.1-90.

BANGA, A.K.; BOSE, S.; GHOSH, T.K. Iontophoresis and electroporation: comparisons and contrasts. Int. J. Pharm., v.179, p.1-19, 1999.

BOUNOURE, F.; SKIBA, M.; BESNARD, M.; ARNAUD, P.; MALLET, E. Effect of iontophoresis and penetration enhancers on transdermal absorption of metopimazine. $J$. Der. Sci., v.52, p.170-177, 2008.

DIMITRIOS, G.F.; JOKE, A.B. Iontophoretic enhancement of Timolol across human dermatomed skin in vitro. J. drug. Targeting, v.12, p.19-24, 2004.

EDSMAN, K.; CARLFORS, J.; HARJU, K. Rheological evaluation and ocular contact time of some carbomer gels for ophthalmic use. Int. J. Pharm., v.137, p.233-241, 1996.

FITZPATRICK, D.; CORISH, J. Release characteristics of anionic drug compounds from liquid crystalline gels III. Chemical and iontophoretic enhancement of delivery across non-rate-limiting membranes. Int. J. Pharm., v.325, p.90-98, 2006 .

FLOREY K. Analytical Profile of drug substances. New York: Academic press, 2005. p.676-681.

GREEN, P.G. Iontophoretic delivery of peptide drugs. J. Contr. Rel., v.41, p.33-48, 1996.

HEIT, M.C.; RIVIERE, J.V. Electrically - assisted transdermal drug delivery. Pharm. Res., v.14, p.687-697, 1997.

JULRAHT, K.; KEITH, A.P.; JAMES, A.W. Development of transdermal delivery device for melatonin: in vivo studies. Drug Dev. Ind. Pharm., v.21, p.1377-1387, 1995.
KALIA, Y.N.; NAIKA, A.; GARRISONC, J.; GUY, R.H. Iontophoretic drug delivery. Adv. Drug Deliv. Rev., v.56, p.619-658, 2004.

KANIKKANNAN, N.; SINGH, J.; RAMARAO, P. Transdermal iontophoretic delivery of timolol maleate in albino rabbits. Int. J. Pharm., v.197, p.69-76, 2000.

KANIKKANNAN, N.; SINGH, J.; SINGH, P. In vitro transdermal iontophoretic transport of Timolol maleate: effect of age and species. J. Contr. Rel., v.71, p.99-105, 2001.

KOTWAL, V.; BHISE, K.; THUBE, R. Enhancement of iontophoretic transport of diphenhydramine hydrochloride thermosensitive gel by optimization of $\mathrm{pH}$, polymer concentration, electrode design and pulse rate. AAPS Pharm. Sci. Tech., v.8, p.E1-E6, 2007.

LAWLER, J.C.; DEVIS, M.J.; GRIFFITH, E. Electrical characteristics of skin: the Impedance of surface sheath and deep tissue. J. Invest. Dermatol., v.34, p.301-308, 1960.

NAIR, A.; VYAS, H.; SHAH, J.; KUMAR, A. Effect of permeation enhancers on the iontophoretic transport of metoprolol tartrate and drug retention in skin. Drug Del., v.18, p.19-25, 2011.

OH, H.; OH, Y.; KIM, C. Effects of vehicles and enhancers on transdermal delivery of melatonin. Int. J. Pharm., v.212, p.63-71, 2001.

PATHAN, I.; MALLIKARJUN, S. Comparison of effect of essential oil on permeation of diclofenac diethylamine through various barriers. Act. Pharm. Sini., v.50, p.219228, 2008 .

PANZADE, P.S.; HEDA, A.; PURANIK, P.K.; PATNI, M.; MOGAL, V. Enhanced transdermal delivery of granisetron by using iontophoresis. Iranian J. Pharm. Res., v.11, p.503$512,2012$.

SARAF, S.; DIXIT, V.K. Influence of electrical factors on in vitro iontophoretic delivery of timolol maleate. Drug Dev. Ind. Pharm., v.22, p.175-179, 1996.

SINGH, P.; HOWARD, I.M. Iontophoresis: an alternative to the use of carriers in cutaneous drug delivery. Adv. Drug Deliv. Rev., v.18, p.379-394, 1996. 
SWEETMAN, S.C. Martindale: the complete drug reference. 35ed. Great Britain: Pharmaceutical press, 2007. p.1269.

VALENTA, C.; AUNER, B.G. The use of polymers for dermal and transdermal delivery. Eur. J. Pharm. Biopharm., v.58, p.279-289, 2004.
ZHANG, I.; SCHUNG, K.K. Hydrogels with enhanced mass transfer for transdermal drug delivery. J. Pharm. Sci., v.85, p.312-316, 1996.

Received for publication on $24^{\text {th }}$ February 2012 Accepted for publication on $26^{\text {th }}$ October 2012 